\title{
The Composition and Compensation of the Board of Directors as Predictors of Corporate Fraud
}

\author{
Joung Yeon $\mathrm{Kim}^{1}$, Dianne M. Roden ${ }^{1} \&$ Steven R. Cox $^{1}$ \\ ${ }^{1}$ School of Business, Indiana University Kokomo, Kokomo, USA \\ Correspondence: Joung Yeon Kim, School of Business, Indiana University Kokomo, Kokomo, IN, 46904, USA. Tel: \\ 1-765-455-9473. E-mail: jyykim@iuk.edu
}

Received: July 23, 2013

Accepted: August 12, 2013

Online Published: August 14, 2013

doi:10.5430/afr.v2n3p142

URL: http://dx.doi.org/10.5430/afr.v2n3p142

\begin{abstract}
We test whether the composition and compensation of the board of directors are related to fraudulent corporate behavior. We use Accounting and Auditing Enforcement Releases from 2003 through 2010 to form a sample of 128 firms with violations and compare the characteristics of their boards to a matched sample of 128 control firms. SEC violations are less likely when the board has more women, independent members, and financial experts. Fraud is also less likely when director tenure is shorter and when the CEO is not the chair. Stock and especially stock option compensation are positively associated with SEC violations.
\end{abstract}

Keywords: Corporate fraud, Audit committee, Director compensation, Board composition

\section{Introduction}

Numerous corporate scandals and volatile market performance have steadily eroded the public's opinion of big business and corporate America. Well-publicized failures of companies such as Enron and WorldCom, along with the financial crisis of 2008, have resulted in a loss of investor confidence and a crisis of trust. Despite extensive accounting reforms including the Sarbanes-Oxley Act, investors' faith in the integrity of corporate executives and the accuracy of their financial reports remains compromised.

This loss of investor confidence is at least partially due to ineffective boards of directors. Corporate boards are responsible for representing external shareholders. This responsibility includes two potentially conflicting roles. One is to ensure management is extracting maximum profitability from the invested capital; the second is an oversight role to ensure ethical behavior and financial statement quality. Active investors and fund managers are increasingly pressuring firms to use performance-based board compensation to encourage directors to push for more profitability. Simultaneously, regulators and investors concerned about stewardship are demanding greater accountability from directors in their oversight role.

Much regulatory attention has been given to the independence of directors and auditors and to imposing fines and penalties for negligence. Less attention has been given to alternative ways of aligning incentives through the selection and compensation of board members. The demographics of the board and their length of service may influence the effectiveness of board members in addressing their potentially conflicting roles. Although the majority of board members must be independent, when stock and stock option compensation is used, it can ultimately result in substantial director ownership. While this ownership may align board member incentives with shareholders, it also potentially compromises director independence.

This comprehensive study is based on all of the Accounting and Auditing Enforcement Releases (AAERs) released by the Securities and Exchange Commission (SEC) from the post-Sarbanes-Oxley period of 2003 through 2010. The composition and compensation of the boards of directors of 128 firms with SEC violations are compared to those of a matched sample of 128 control firms. The paper contributes to the existing literature by examining fraud in the post-Sarbanes-Oxley period, while most research (Beasley, 1996; Dechow, Sloan, \& Sweeney, 1996; Persons, 2012; Vafeas, 2005) has been based on earlier periods. In addition, our sample is based on all SEC violations during this period, compared to other studies (Archambeault, DeZoort, \& Hermanson, 2008; Boumosleh 2009; Cullinan, Du, \& Wright, 2008; Srinidhi, Gul, \& Tsui, 2011; Vafeas, 2005) that looked at samples of firms with selected violations or financial restatements not necessarily associated with fraud. This study is also unique in that it combines characteristics of both the composition and compensation of the board of directors and the associated audit committee. 
We find that the likelihood of fraud increases significantly when the CEO also serves as chair of the board, when board members have longer tenure, and when fewer women sit on the board. These results contrast with several studies (Ghosh, Mara, and Moon, 2010; Sun, Liu, \& Lan, 2011) that reported ambiguous or mixed results with these variables. In addition, we find stock compensation is positively associated with fraud. However, conflicts of interest and likelihood of fraud are much greater for stock options than for common stock compensation. These results indicate that the composition and compensation of a board of directors may result in misaligned incentives that compromise the oversight role. Important policy implications follow from these findings.

The next section of this paper reviews the relevant literature. Section 3 describes our data and model development, Section 4 presents our results, and Section 5 provides a summary and discusses policy implications.

\section{Literature review}

The separation of ownership and management in corporations has necessitated a monitoring mechanism to protect shareholders from management's self-interested decisions. The key monitoring body is the board of directors and its subcommittees that oversee financial statement reporting and determine appointment and compensation of top management on behalf of shareholders. The effectiveness of this monitoring function is likely to be influenced by the composition and compensation of the board members.

\subsection{Composition of the Board}

\subsubsection{Board Independence}

Prior research documented that a higher proportion of outside directors is associated with a higher quality of reported earnings due to the enhanced independence of boards (Beasley, 1996; Dechow et al., 1996; Klein, 2002; Vafeas, 2005). Inside directors, who are also top management, provide valuable knowledge about corporate operations to the board discussions, but they have incentive to hide poor performance in order to secure their jobs and related compensation. Their insider knowledge and full-time status can easily transform the board of directors into an instrument of management at the expense of shareholder interests (Williamson, 1984). On the other hand, outside directors have strong incentives to perform their monitoring duties diligently to protect their reputation in the external directorship markets (Vafeas, 2005; Maggina \& Tsaklanganos, 2012). Due to external markets that reward and punish outside directors (Beasley \& Salterio, 2001; Kaplan \& Reishus, 1990), these directors are more likely to be diligent in constraining practices that deteriorate financial statement quality or violate securities laws.

\subsubsection{Segregation of the Board Chair and CEO Positions}

Management can hinder an outside director's monitoring activities by taking advantage of inside knowledge as well as the CEO's influence when the CEO also serves as board chair (Beasley \& Salterio, 2001). Jensen (1993) argued that it is important to separate the chair and CEO positions to have an effective board. Dechow et al. (1996) provided evidence of association between earnings management and the CEO simultaneously serving as chair. An analysis of 627 Canadian firms by Beasley \& Salterio (2001) showed firms that separate the chair and CEO positions are more likely to voluntarily improve the quality of their audit committees by including more outsiders. On the other hand, Ghosh et al. (2010) found no relationship between earnings management and separation of the chair and CEO positions.

Of course, the separation of the chair and CEO positions may have implications beyond the likelihood of fraud. Krause and Semadeni (2013) found that separating the two positions decreased shareholder returns when the firm was performing well and increased shareholder returns when firms were struggling.

\subsubsection{Director Length of Tenure and Age}

The literature presents two conflicting views on the relationship between director tenure length and the effectiveness of boards. More experienced directors who have served longer on the board can provide better knowledge about the firm and be more efficient in decision making. Such extended board service may indicate director commitment. Ghosh et al. (2010) analyzed the data of post-Sarbanes-Oxley Act years and reported a negative relationship between the average tenure of audit committee directors and discretionary accruals. This suggests that audit committee directors with longer tenure are more effective in mitigating earnings management. On the other hand, more seasoned directors have been shown to lose their independence over time and favor management's interests over shareholders' (Vafeas, 2005). Directors who have served for an extended time are likely to befriend management (Vafeas, 2003).

While there is limited research relating to the impact of the age of directors on fraudulent behavior, many business studies have found positive relationships between age and ethical behavior (Peterson, Rhoads, \& Vaught, 2001; Borkowski \& Ugras, 1998). 


\subsubsection{Women on the Board}

A growing body of literature focuses on the role of female directors in board effectiveness. Several researchers found no gender differences in ethical judgments among business practitioners (Sun et al., 2011; Shafer, Morris, \& Ketchand 2001; Razzaque \& Hwee, 2002; Abdolmohammadi, Read, \& Scarbrough, 2003; Ballantine, 2011). On the other hand, Gavious, Segev, \& Yosef (2012) found a negative relationship between the presence of female directors and earnings management. They argued that aggressive accounting decisions are mitigated in proportion to the number of women on the board of directors and the audit committee. Srinidhi et al. (2011) showed that female board participation is associated with higher quality of reported earnings. Adams and Ferreira (2009) found that female directors have significant positive impact on board performance through better attendance records and by being more likely to join monitoring committees charged with transparent reporting. They also found that male directors have fewer attendance problems the more gender-diverse the board is. Other studies also showed that the presence of women improves both board effectiveness and firm performance (Huse \& Solberg, 2006; Campbell \& Minguez-Vera, 2008).

Female board participants improve a board's monitoring quality by diversifying the boardroom. Women present different viewpoints, demand different perspectives, and facilitate well-informed decisions, all of which are crucial for effective oversight (Rose 2007; Srinidhi et al., 2011). Female directors do not belong to old-boy networks and are more likely to provide constructive criticism and independent thinking (Adams \& Ferreira, 2009). Gender-diverse boards are also more civilized in culture (Bilimoria, 2000; Fondas \& Sassalos, 2000).

A number of studies showed that women are generally more risk-averse and less tolerant of opportunistic behavior than men (Ambrose \& Schminke, 1999; Thorne, Massey, \& Magnan, 2003; Krishnan \& Parsons, 2008). Cox and Radtke (2000) found that women tax preparers felt more accountability to compliance with tax laws than men. Studies have also demonstrated that women are more cautious and their business judgments are more ethical (Vermeir \& Van Kenhove, 2007). Kaplan, Pany, Samuels, \& Zhang (2009) found women more likely to report fraudulent financial reporting.

\subsection{Compensation of the Board}

Compensation to outside board members is typically through combinations of cash, stock, and stock options. While a high level of total compensation is necessary to attract and retain quality directors, the mix of this compensation can be used as a tool to align the interests of directors with the owners they represent. Although performance-based compensation through equity aligns director and shareholder profit motives, outside directors are also expected to play a key role in preventing and challenging misconduct and wrongdoing by management. Directors may struggle to perform in this monitoring role when the form of their compensation compromises their independence. The literature provides evidence that an improperly aligned compensation scheme, such as stock and stock options, compromises a director's independence and impairs their ability to provide objective oversight (Hamdani \& Kraakman, 2007; Archambeault et al., 2008; Cullinan et al., 2008; Boumosleh, 2009; Bebchuk, Grinstein, \& Peyer, 2010; Persons, 2012; Bierstaker, Cohen, DeZoort, \& Hermanson, 2012 ).

\subsubsection{Cash Compensation}

Cash, typically annual retainers and meeting fees, is a popular form of director compensation. In a study examining the relationship between CEO and director compensation and boardroom culture, Brick, Palmon, \& Wald (2006) argued that excessive cash compensation for executives and directors may be associated with a culture of cronyism. In contrast, Crutchley \& Minnick (2012) examined a sample of lawsuits filed against directors from 1995 to 2001 and found that greater cash compensation for directors reduces the likelihood of a lawsuit while higher incentive-based pay is associated with a greater incidence of lawsuits. An empirical study by Persons (2012) indicated no significant association between directors' cash compensation and the likelihood of fraud. These results indicate that cash compensation may establish a better agency relationship between directors and shareholders than equity-based compensation.

\subsubsection{Stock Compensation}

Stock compensation, like stock options, is incentive-based equity compensation with the potential downside of providing executives and directors motivation to manipulate earnings to augment their personal wealth (Cullinan et al., 2008; Persons, 2012). Vnuk and Laddin (2010) and Persons (2012) reported an increase in the use of restricted stock and a simultaneous decline in stock options for director compensation. However, there are only a few studies that examined the particular impact of stock compensation. Cullinan et al. (2008) found no association between director stock compensation and the probability of misstatements. In addition, Persons (2012) found no association between directors' stock ownership and fraud likelihood. 
In contrast to stock compensation, Cullinan et al. (2008) and Chowdhury (2009) argued that directors paid with stock options experience little personal loss from market declines because of the low fair value of options when granted. Therefore, the downside risk for directors is much lower with stock options than stock (Chowdhury, 2009). As a result, stock compensation is less likely to be associated with excessive risk taking than stock option compensation (Sanders \& Hambrick, 2007).

\subsubsection{Stock Option Compensation}

Since the 1990s, many corporations have used stock options to compensate their independent directors. Proponents of stock option compensation (Jensen 1993) argue that it aligns shareholders' and directors' interests, thereby motivating vigilant supervision of management to enhance the firm's stock price. However, a growing body of literature (Archambeault et al., 2008; Boumosleh, 2009; Cullinan et al., 2008) indicates that stock option compensation actually aligns the interests of directors with those of top managers, instead of shareholders, and thereby reduces director independence.

Using a sample of 105 U.S. firms that misstated revenue and a matched sample of non-misstating firms, Cullinan et al. (2008) found that companies with stock option-compensated independent directors are more likely, intentionally or not, to misstate revenues. They argued that compensating outside directors with stock options weakens independent oversight by creating reciprocal interests between directors and management, rather than between directors and shareholders. Archambeault et al. (2008) analyzed a sample of 153 restatement firms and a matched sample of 153 non-restating firms and found a positive relationship between stock option compensation for audit committee members and the incidence of fraudulent or erroneous financial restatement.

There is evidence of a link between director stock option compensation and intentional fraudulent financial reporting. Boumosleh (2009) found director stock options positively associated with earnings management and concluded that option compensation provides financial incentives for a director to fail to diligently monitor the financial reporting process. Bebchuk et al. (2010) studied a duplicitous corporate practice that grants options to directors and CEOs when the stock prices were at their lowest value. The study finds that such "lucky grants" were back-dated from their actual grant date to maximize option value. Persons (2012) showed a positive association between director stock option compensation and fraudulent financial reporting based on an empirical analysis of 111 fraudulent companies during the period just before Sarbanes-Oxley. The law literature has also recognized that stock options reduce directors' incentives towards diligent monitoring duty and encourages directors to overlook wrongdoing of management. Hamdani and Kraakman (2007) argued that directors with stock options have little incentive to uncover wrongdoing because disclosing bad news usually means a decline of share price (Palmrose, Richardson, \& Scholz, 2004) and consequently a loss of directors' income.

\section{Data and Model Development}

We examine characteristics of the board of directors to predict fraudulent behavior. We select a number of explanatory variables that reflect the composition and compensation of the board and predict the direction of the relationship with corporate fraud. The model is tested using logistic regressions where the dependent variable equals one if a firm committed a SEC violation and zero if a firm is a matched control. This model is represented below:

$$
\text { Fraud }(0,1)=a+b_{i} \text { [control variables] }+c_{i} \text { [composition variables] }+d_{i} \text { [compensation variables] }+e_{\mathrm{i}}
$$

\subsection{The Violators Sample}

We formed a sample of firms by reviewing all of the AAERs reported by the SEC from 2003 through 2010. We summarized the releases by identifying the company name, type of violation, and the relevant years involved. There were 211 firms with at least one federal securities violation during this post-Sarbanes-Oxley period.

Table 1 summarizes the five main types of AAER violations in the original sample of 211 firms. By far the most common violation $(52.1 \%$ of the total) was earnings management. Often revenues were inflated or expenses were understated in an effort to meet analysts' estimates. Many cases involved "prematurely recognizing revenue," while others involved complex schemes to "fraudulently inflate reported revenue by creating fictitious customers" or "bogus sales orders and phony revenue." The descriptions in the enforcement releases were consistent with managers and executives responding to pressure to meet ambitious goals. A typical AAER statement described a firm using "fraudulent accounting practices to inflate earnings to meet forecasts."

The second most common type of violation ( $23.7 \%$ of sample firms) was a failure to disclose material information, such as the riskiness of loans or mortgages. Typical AAERs included firms that "failed to disclose related-party transactions" and firms that "deliberately misled investors about significant risks being taken." There were also cases 
(14.2\%) of bribing foreign officials, including reports of "deliveries of cash-filled briefcases to government officials to win sales contracts."

There were less frequent incidents (10.4\%) of firms backdating stock options. A typical enforcement release described "backdated documents to conceal they were using in-the-money option grants and providing executives with undisclosed compensation." Finally, $10.0 \%$ of the firms were charged with embezzlement, where managers directly misappropriated funds for their personal benefit. A typical example of embezzlement involved a senior executive who "systematically withdrew company funds and transferred them to a personal account to fund his lavish lifestyle." Just over $10 \%$ of the firms had simultaneous violations, typically involving earnings manipulations combined with another infraction.

Table 1. Types of AAER Violations in Original and Final Matched Sample

\begin{tabular}{lrrrr}
\hline Type of Accounting and Auditing Enforcement & $\begin{array}{c}\text { Firms in } \\
\text { Original } \\
\text { Selease Violation }\end{array}$ & $\begin{array}{c}\text { Percentage in } \\
\text { Original } \\
\text { Sample }\end{array}$ & $\begin{array}{c}\text { Firms in } \\
\text { Final } \\
\text { Sample }\end{array}$ & $\begin{array}{c}\text { Percentage } \\
\text { in Final } \\
\text { Sample }\end{array}$ \\
\hline Earnings Manipulation (EM) & 110 & 52.1 & 76 & 59.4 \\
Failure to Disclose Material Information (FD) & 50 & 23.7 & 22 & 17.2 \\
Bribing Foreign Officials (BFO) & 30 & 14.2 & 14 & 10.9 \\
Backdating Stock Options (BSO) & 22 & 10.4 & 20 & 15.6 \\
Embezzlement (EBZ) & 21 & 10.0 & 9 & 7.0 \\
Firms with Double Violations & $\underline{(22)}$ & $\underline{(10.4)}$ & $\underline{(13)}$ & $\underline{10.2)}$ \\
Total Number of Fraud Companies & 211 & 100.0 & 128 & 100.0 \\
\hline
\end{tabular}

For each sample firm with a securities violation, we searched the SEC EDGAR web site for a proxy statement from the first fraudulent year. If a proxy statement was not available during the first fraudulent year, then the proxy statement from the next available year during the firm's violation period was substituted. There were 67 firms without available proxy statements, typically because they were foreign entities or very small. There were nine firms without financial data on COMPUSTAT and another seven firms without a matching control firm (the control sample is discussed in the next section), resulting in a final sample of 128 fraud firms. The percentages of each type of violation in the final sample are similar to those in the original sample.

\subsection{The Control Sample}

Following the methodology of Beasley (1996), we created a control sample designed to match size and industry in the year prior to the first year of the financial statement fraud. A step-wise process was used to identify matching firms by satisfying the following conditions:

1) The firm was not reported in AAER for violating financial reporting regulations from 2003 through 2010.

2) The firm's financial data was available in COMPUSTAT for the year prior to the first year of the fraud firm's violations reported in AAER.

3) The firm was classified in the same four-digit SIC code as the fraud company.

4) The firm's market value of common equity was the closest to that of the given fraud firm among the no-fraud firms satisfying the first three conditions. The size of the matched control firm was required to be within $30 \%$ of the size of the fraud firm.

5) If no matching firm was found in condition 4, we modified condition 3 by using a two-digit SIC code instead of the four-digit code. Conditions 1 through 4 were then repeated with modified condition 3 . This allowed a larger pool by broadening the industry classification.

6) If a matching firm was still not found, we modified condition 4 by replacing market value of equity with net assets and repeated conditions 1 through 5 . Most cases in this category were due to missing parameters necessary for computing the market value of equity, which made the original condition 4 infeasible.

\subsection{Data Collection}

Data regarding board composition and compensation for all firms comes from the collected proxy statements, reflecting the board characteristics of the violating and matched firms in the year prior to the first violation. Data was collected describing the composition of the full board of directors, including the number of members, their 
independence, age, number of years on the board, length of elected term, gender, financial and accounting expertise, and whether the CEO was also chair. The same basic data was also collected for the audit committee, a subset of the full board made up of only independent directors. The proxy statements also provided information about the compensation to the outside (non-management) directors. This typically included an annual cash retainer, meeting fees, and in some cases common stock and stock options. Any additional payments made to the audit committee or its chair were also recorded.

Financial information used to construct the matched sample and to create control variables comes from COMPUSTAT from the year preceding the first year of violation. Any data not found on COMPUSTAT was collected from individual financial statements found on the SEC EDGAR site.

\subsection{Variable Measurements and Predicted Relationships}

Previous research has shown that board member independence is clearly linked to higher quality financial reporting and more effective governance. (Beasley, 1996; Dechow et al., 1996; Klein, 2002; Vafeas, 2005) We measure independence as the percentage of independent board members as declared in the proxy statement and expect to find a negative relationship with the likelihood of fraud. We also measure the percentage of accounting/finance experts on the board and expect a negative relationship with the likelihood of fraud. The Sarbanes-Oxley Act, which requires all audit committee members to be independent and at least one member to be a financial expert, supports the above predictions.

The mean age of each firm's board has the potential for conflicting impacts on the likelihood of fraud. Ethics studies support the general presumption that wisdom and ethical behavior come with age (Peterson et al., 2001). On the other hand, age is likely to be positively associated with length of time on the board and the attendant negative externalities associated with an entrenched board. Because we will control for the length of time with the firm, we predict a negative relationship between age and the likelihood of fraud. We also measure the percentage of women on the board. Women offer diverse experiences that broaden the perspective of the board and help to modify board behavior (Gavious et al., 2012). The presence of females may also serve as a proxy for open-minded, less entrenched firms. As a result, we expect a negative relationship between the percentage of females and the likelihood of fraud.

Tenure is measured as the mean number of years served by the board members at the time of the proxy statement. While experienced directors may gain firm and industry knowledge, seasoned directors have been shown to lose their independence over time and favor management's interests over shareholders' (Vafeas, 2005; Vafeas, 2003). Therefore, we predict a positive relationship between tenure and the likelihood of a violation.

To measure the impact of a firm combining its top two leadership positions, we created a dummy variable set to one if the chair was also the firm's CEO, and zero otherwise. While there are potential profit motivations for combining these positions, the risk is that the oversight function of the board may be compromised (Jensen, 1993; Dechow et al., 1996). Based on the potential conflicts of interest between the two positions, we expect a positive relationship between this dummy variable and the likelihood of fraud.

In addition to examining the impact of the composition of the board on fraudulent behavior, we also consider the impact of board compensation to outside directors. Compared to performance-based compensation, cash compensation is likely to be more effective in ensuring that directors maintain their oversight function. However, this does not mean that more cash compensation will reduce fraud. Past research has found no association between the likelihood of fraud and outside directors' cash compensation (Persons, 2012). Therefore, we do not expect a significant relationship with annual cash retainers or meeting fees (measured in thousands of dollars on an annual basis) with the likelihood of fraud.

Offering equity compensation may promote director behavior that prioritizes maximizing stock value. However, while long-term stock holdings may help align incentives with owners, common stock compensation may compromise director independence and impair their ability to provide objective oversight. As directors' compensation becomes more closely tied to stock prices, the incentives to tolerate manipulation of earnings and the hiding of poor performance are increased. However, limited prior research has not found a relationship between stock compensation to directors and incidents of fraud or erroneous financial statements (Persons, 2012; Cullinan et al., 2008). We measure common stock compensation in thousands of dollars on an annual basis based on the stock price at the time of the proxy statement. Due to the conflicting theoretical effects of stock compensation and the inconclusive past empirical results, we do not predict a relationship to the likelihood of fraud.

The magnitude of the positive and negative effects of equity compensation is significantly increased when stock options are used as compensation. The literature provides strong evidence that stock option compensation encourages short-term manipulation of earnings and weakens independent oversight (Archambeault et al., 2008; Cullinan et al., 
2008; Persons, 2012). We measure stock option compensation in thousands of dollars on an annual basis based on the value given in the proxy statement. These option values were typically calculated using the Black-Scholes-option-pricing model. We expect a positive relationship between stock option compensation and the likelihood of fraud.

Our model controls for size, leverage, and profitability. Size is measured as the log of total assets expressed in thousands of dollars. Leverage is measured as the debt ratio defined as total debt divided by total assets. Profitability is measured by return on assets (ROA) computed as net income divided by total assets. Because the control firms are matched to violator firms based on size and industry, we do not expect a significant relationship between these variables and the likelihood of fraud.

\section{Results}

\subsection{Mean Results}

Table 2 shows mean values of selected variables for the samples of violators and control firms. As expected, control variables are not significantly different between the samples. Debt ratios are relatively high (55\% in both samples) and mean ROA is negative for both samples. These results may reflect firms under financial pressure with greater concerns about meeting investor expectations. The negative mean earnings may also reflect that our sample period (2003 -2010) includes the financial crisis that started in 2008.

With regard to the composition of the board members, average age is not different between the two samples, but violator firms have board members with more years of service. Violator firms have significantly fewer independent members and female members. In fact, the control firms have almost twice as many women directors (12.1\% versus $6.7 \%$ ). While $53 \%$ of violator firms have CEOs that also served as chair, only $35 \%$ of control firms utilize CEOs in that dual role. The audit committees of violator firms also have longer tenure and fewer women.

In terms of compensation of board members, the mean stock option compensation is four times larger for violator firms. Total compensation is also significantly higher. This difference is primarily driven by the difference in option compensation, as the other forms of compensation are not significantly different. Extra compensation for the members of the audit committee is significantly higher for violator firms.

Finally, there are no significant differences between the samples regarding characteristics of the audit firm; except predictably, auditor change is more than twice as likely for violator firms during their fraud period.

\subsection{Analysis of the Board of Directors}

Table 3 shows the results from four logistic regressions with the dependent variable equal to one if the firm is a violator and zero if the firm is a control firm. In the first regression only control variables are included and none of the total variability is explained. Total assets is not a significant variable because the control firms were matched to the fraud firms based on size. Return on assets and the debt ratio are not significant variables because the control firms were matched to the fraud firms based on industry, which should proxy for profitability and leverage.

The second regression includes control and composition variables. A significant positive coefficient is found based on the average length of service on the board. This is consistent with entrenched boards being more likely to commit or tolerate fraud (Vafeas, 2003). Age of the board members and the length of each elected term are not significant. Significantly negative coefficients are found on the percentage of independent board members and the percentage of women on the board. The importance of outside directors is well established in the literature (Beasley, 1996; Klein, 2002). The significance of the percentage of females is particularly strong. The presence of women may prevent an otherwise entrenched board from acting unilaterally. Finally, a significant positive coefficient is found on the dummy variable indicating firms where the $\mathrm{CEO}$ is also chair. When these two positions are combined, fraud is more likely. This regression has significant explanatory power (pseudo $\mathrm{R}^{2}$ of $16 \%-22 \%$ ).

The third regression includes control and compensation variables and has slightly more explanatory power (pseudo $\mathrm{R}^{2}$ of $21 \%-28 \%$ ). Both common stock and stock option compensation are significantly positive. The coefficient for stock option compensation is larger and more significant than the coefficient for stock compensation. Cash-based compensation is not associated with increased risk of fraud.

The fourth regression includes the control, composition, and compensation variables. The regression has significant ability to predict fraud firms (pseudo $\mathrm{R}^{2}$ of $34 \%-45 \%$ ). All variables that were significant in the previous regressions remain significant with the same sign. In addition, the coefficient on the percent of finance and accounting professionals on the board is significantly negative. When more board members have finance and accounting backgrounds, fraud is less likely. 
Overall, the likelihood of corporate fraud is significantly affected by both the composition and compensation of the board of directors. With regard to composition, fraud is more likely when an entrenched board compromises the oversight function of the board of directors. Specifically, increased turnover on the board that reduces average tenure is associated with reduced likelihood of fraud. Note that the length of the elected term does not seem to matter. Instead, it is the total length of time served on the board that is significant. Including more women, finance and accounting professionals, and independent directors to the board can further reduce entrenchment. The oversight function of the board also appears to be compromised when the CEO serves as the chair. Our strong results relating to the impact of women on the board, the average tenure, and the CEO also serving as chair, contrast with earlier studies with ambiguous or mixed results with these variables. (Sun et al., 2011; Ghosh et al., 2010)

Table 2. Mean Results by Category

\begin{tabular}{|c|c|c|c|}
\hline & $\begin{array}{l}\text { Violators' Mean } \\
\quad(n=128)\end{array}$ & $\begin{array}{l}\text { Controls' Mean } \\
(\mathrm{n}=128)\end{array}$ & $t$-value \\
\hline \multicolumn{4}{|l|}{ Control Variables } \\
\hline Total Assets (000) & $\$ 9,897,530$ & $\$ 7,830,764$ & 0.39 \\
\hline Debt Ratio (Total Liabilities/Total Assets) & $54.82 \%$ & $55.28 \%$ & -0.11 \\
\hline Return on Assets (Net Income/Total Assets) & -0.0160 & -0.0251 & 0.21 \\
\hline \multicolumn{4}{|l|}{ Composition Variables } \\
\hline Average age of board members & 57.54 & 57.28 & 0.41 \\
\hline Average number of years on the board & 6.90 & 5.88 & 2.75 \\
\hline Average term length for board members & 2.06 & 2.00 & 0.49 \\
\hline$\%$ of independent members on the board & 71.36 & 75.28 & -2.79 \\
\hline$\%$ of women on the board & 6.74 & 12.12 & -4.50 \\
\hline$\%$ of finance/accounting experts on the board & 44.91 & 46.66 & -0.86 \\
\hline$\%$ of CEO also the chair of the board & 53.13 & 35.15 & 2.94 \\
\hline Average age of the audit committee & 58.87 & 57.43 & 2.00 \\
\hline Average number of years on audit committee & 6.20 & 5.32 & 2.53 \\
\hline$\%$ of females on the audit committee & 6.89 & 14.00 & -3.43 \\
\hline$\%$ of finance/accounting experts on audit committee & 61.42 & 60.57 & 0.29 \\
\hline \multicolumn{4}{|l|}{ Compensation Variables } \\
\hline Meeting fees for board members & $\$ 8,870$ & $\$ 8,404$ & 0.43 \\
\hline Cash retainer for board members & $\$ 25,944$ & $\$ 21,914$ & 1.70 \\
\hline Stock compensation for board members & $\$ 15,901$ & $\$ 14,715$ & 0.30 \\
\hline Stock options for board members & $\$ 43,631$ & $\$ 10,758$ & 6.66 \\
\hline Total compensation for board members & $\$ 94,346$ & $\$ 55,790$ & 5.59 \\
\hline Audit committee compensation (extra) & $\$ 10,583$ & $\$ 7,033$ & 2.72 \\
\hline Chair of audit committee compensation (extra) & $\$ 6,788$ & $\$ 5,646$ & 1.32 \\
\hline \multicolumn{4}{|l|}{ Audit Variables } \\
\hline$\%$ with Big 4 auditor & 84.38 & 88.28 & -0.91 \\
\hline Total fees paid & $\$ 3,954,292$ & $\$ 2,924,007$ & 1.16 \\
\hline$\%$ of fees for audit & 79.56 & 80.15 & -0.74 \\
\hline$\%$ with auditor change during fraud period & 33.59 & 15.63 & 3.41 \\
\hline
\end{tabular}

With regard to compensation, fraud is more likely at firms that offer directors incentive-based compensation, such as common stock and especially stock options. Performance-based incentives reduce the incentive to uncover 
wrongdoing because disclosing bad news means a decline in share values. Stock option compensation, in particular, appears to reduce the independence of the board and introduces a conflict of interest in the oversight role.

All of the above regression results remain qualitatively the same when the sample is segregated by type of violation (not reported in our tables). Each type of AAER violation involves the intentional use of fraudulent accounting practices and appears to be impacted by the same composition and compensation variables.

Table 3. Logistic Regressions Using Characteristics of the Board of Directors to Predict Fraudulent Behavior

\begin{tabular}{|c|c|c|c|c|c|}
\hline & $\begin{array}{l}\text { Expected } \\
\text { Sign }\end{array}$ & $\begin{array}{c}\text { Control } \\
\text { Variables }\end{array}$ & $\begin{array}{l}\text { Composition } \\
\text { Variables }\end{array}$ & $\begin{array}{c}\text { Compensation } \\
\text { Variables }\end{array}$ & $\begin{array}{c}\text { All } \\
\text { Variables }\end{array}$ \\
\hline $\ln$ (Total Assets) & $\mathrm{n} / \mathrm{a}$ & $\begin{array}{r}0.024 \\
(.679)\end{array}$ & $\begin{array}{r}0.122 \\
(.090)\end{array}$ & $\begin{array}{r}-0.064 \\
(.438)\end{array}$ & $\begin{array}{r}-0.026 \\
(.795)\end{array}$ \\
\hline Return on Assets & $\mathrm{n} / \mathrm{a}$ & $\begin{array}{r}0.052 \\
(.891)\end{array}$ & $\begin{array}{l}0.056 \\
(.900)\end{array}$ & $\begin{array}{l}0.298 \\
(.455)\end{array}$ & $\begin{array}{r}0.341 \\
(.482)\end{array}$ \\
\hline Debt Ratio & $\mathrm{n} / \mathrm{a}$ & $\begin{array}{l}-0.103 \\
(.801)\end{array}$ & $\begin{array}{l}0.118 \\
(.803)\end{array}$ & $\begin{array}{l}0.057 \\
(.897)\end{array}$ & $\begin{array}{l}0.309 \\
(.559)\end{array}$ \\
\hline Average Age of Board Members & - & & $\begin{array}{r}-0.047 \\
(.160)\end{array}$ & & $\begin{array}{r}-0.063 \\
(.109)\end{array}$ \\
\hline Average Number of Years on Board & + & & $\begin{array}{r}0.108 \\
(.050)\end{array}$ & & $\begin{array}{r}0.148 \\
(.018)\end{array}$ \\
\hline Term Length on Board & + & & $\begin{array}{l}0.060 \\
(.669)\end{array}$ & & $\begin{array}{l}0.211 \\
(.180)\end{array}$ \\
\hline$\%$ of CEO is also chair of board & + & & $\begin{array}{r}0.828 \\
(.004)\end{array}$ & & $\begin{array}{r}0.690 \\
(.033)\end{array}$ \\
\hline$\%$ of Women on Board & - & & $\begin{array}{r}-0.073 \\
(.000)\end{array}$ & & $\begin{array}{r}-\mathbf{0 . 0 8 3} \\
(.000)\end{array}$ \\
\hline $\begin{array}{l}\% \text { of Fin./Acct. Professionals on } \\
\text { Board }\end{array}$ & - & & $\begin{array}{r}-0.013 \\
(.141)\end{array}$ & & $\begin{array}{r}-0.023 \\
(.030)\end{array}$ \\
\hline$\%$ of Independent Members on Board & - & & $\begin{array}{r}-0.029 \\
(.028)\end{array}$ & & $\begin{array}{r}-0.044 \\
(.005)\end{array}$ \\
\hline Cash Retainer (000) & ? & & & $\begin{array}{l}0.005 \\
(.570)\end{array}$ & $\begin{array}{l}0.017 \\
(.148)\end{array}$ \\
\hline Meeting Fees (000) & ? & & & $\begin{array}{r}-0.003 \\
(.886)\end{array}$ & $\begin{array}{l}0.000 \\
(.999)\end{array}$ \\
\hline Common Stock Compensation (000) & ? & & & $\begin{array}{r}0.010 \\
(.048)\end{array}$ & $\begin{array}{l}0.015 \\
(.009)\end{array}$ \\
\hline Stock Option Compensation $(000)$ & + & & & $\begin{array}{r}0.043 \\
(.000)\end{array}$ & $\begin{array}{r}0.042 \\
(.000)\end{array}$ \\
\hline Constant & $\mathrm{n} / \mathrm{a}$ & $\begin{array}{r}-0.089 \\
(.812)\end{array}$ & $\begin{array}{l}4.109 \\
(.040)\end{array}$ & $\begin{array}{r}-0.753 \\
(.097)\end{array}$ & $\begin{array}{r}5.433 \\
(.023)\end{array}$ \\
\hline \# of observations & & 256 & 256 & 256 & 256 \\
\hline Chi-squared significance & & .972 & .000 & .000 & .000 \\
\hline Cox \& Snell $\mathrm{R}^{2}$ & & .001 & 164 & .208 & .338 \\
\hline Nagelkerke $\mathrm{R}^{2}$ & & .001 & 219 & .278 & .451 \\
\hline
\end{tabular}

(Coefficient results for each independent variable are followed by p-values below.)

\subsection{Analysis of the Audit Committee}

Table 4 shows the results from four logistic regressions using the characteristics of the audit committee instead of the entire board as in Table 3. Again, the dependent variable equals one if the firm is a violator and zero if the firm is a control firm. As in the previous regressions, the control variables are not significant. In the second regression, the composition of the audit committee has less explanatory power than the characteristics of the full board because the audit committee is a small subset of the full board, and regulations require that all audit committee members be independent and that at least one member must be a finance/accounting expert. Consistent with results for the entire 
board, fraud is more likely when the average years served on the audit committee is longer, indicating potential entrenchment. Also consistent with previous results, fraud is less likely when females are on the audit committee.

The third regression includes compensation to all outside board members plus any additional compensation to members of the audit committee. As in Table 3, stock and stock option compensation to all outside board members are positively related to fraud. Additional compensation to the audit committee is also positively related to fraud. The additional compensation to the audit committee members increases the explanatory power (pseudo $\mathrm{R}^{2}$ increases by $2 \%$ - 3\%). Compensation to the audit committee chair beyond the compensation to the whole audit committee is not significant.

In the final regression, when all variables are included, the relationships described above remain unchanged. The overall pseudo $\mathrm{R}^{2}$ values are roughly equal to the sum of those in the individual composition and compensation models, indicating that both sets of characteristics are important.

Table 4 Logistic Regressions Using Characteristics of the Audit Committee to Predict Fraudulent Behavior

\begin{tabular}{|c|c|c|c|c|c|}
\hline & $\begin{array}{l}\text { Expected } \\
\text { Sign }\end{array}$ & $\begin{array}{c}\text { Control } \\
\text { Variables }\end{array}$ & $\begin{array}{l}\text { Composition } \\
\text { Variables }\end{array}$ & $\begin{array}{c}\text { Compensation } \\
\text { Variables }\end{array}$ & $\begin{array}{c}\text { All } \\
\text { Variables } \\
\end{array}$ \\
\hline $\ln$ (Total Assets) & $\mathrm{n} / \mathrm{a}$ & $\begin{array}{r}0.024 \\
(.679)\end{array}$ & $\begin{array}{r}0.023 \\
(.724)\end{array}$ & $\begin{array}{r}-0.085 \\
(.323)\end{array}$ & $\begin{array}{r}-0.118 \\
(.222)\end{array}$ \\
\hline Return on Assets & $\mathrm{n} / \mathrm{a}$ & $\begin{array}{l}0.052 \\
(.891)\end{array}$ & $\begin{array}{r}-0.056 \\
(.888)\end{array}$ & $\begin{array}{l}0.237 \\
(.562)\end{array}$ & $\begin{array}{l}0.303 \\
(.524)\end{array}$ \\
\hline Debt Ratio & $\mathrm{n} / \mathrm{a}$ & $\begin{array}{l}-0.103 \\
(.801)\end{array}$ & $\begin{array}{l}0.093 \\
(.826)\end{array}$ & $\begin{array}{r}0.089 \\
(.844)\end{array}$ & $\begin{array}{l}0.304 \\
(.533)\end{array}$ \\
\hline $\begin{array}{l}\text { Average Age of Audit Committee } \\
\text { Members }\end{array}$ & - & & $\begin{array}{l}0.014 \\
(.606)\end{array}$ & & $\begin{array}{l}0.000 \\
(.999)\end{array}$ \\
\hline Average Years on Audit Committee & + & & $\begin{array}{r}0.097 \\
(.065)\end{array}$ & & $\begin{array}{l}0.117 \\
(.059)\end{array}$ \\
\hline$\%$ of Women on Audit Committee & - & & $\begin{array}{r}-0.026 \\
(.002)\end{array}$ & & $\begin{array}{r}-0.031 \\
(.002)\end{array}$ \\
\hline $\begin{array}{l}\% \text { of Fin./Acct. Professionals on Audit } \\
\text { Committee }\end{array}$ & - & & $\begin{array}{r}-0.002 \\
(.759)\end{array}$ & & $\begin{aligned}-0.011 \\
(.109)\end{aligned}$ \\
\hline Cash Retainer (000) & ? & & & $\begin{array}{r}-0.001 \\
(.930)\end{array}$ & $\begin{array}{r}-0.002 \\
(.875)\end{array}$ \\
\hline Meeting Fees $(000)$ & ? & & & $\begin{array}{r}-0.020 \\
(.353)\end{array}$ & $\begin{array}{r}-0.026 \\
(.258)\end{array}$ \\
\hline Common Stock Compensation (000) & ? & & & $\begin{array}{l}0.009 \\
(.089)\end{array}$ & $\begin{array}{r}0.012 \\
(.031)\end{array}$ \\
\hline Stock Option Compensation (000) & + & & & $\begin{array}{l}0.045 \\
(.000)\end{array}$ & $\begin{array}{l}0.048 \\
(.000)\end{array}$ \\
\hline $\begin{array}{l}\text { Extra Audit Committee Compensation } \\
(000)\end{array}$ & + & & & $\begin{array}{l}0.052 \\
(.010)\end{array}$ & $\begin{array}{l}0.053 \\
(.015)\end{array}$ \\
\hline $\begin{array}{l}\text { Extra Audit Committee Compensation } \\
\text { (000) (For Chair) }\end{array}$ & + & & & $\begin{array}{r}-0.005 \\
(.847)\end{array}$ & $\begin{array}{l}0.011 \\
(.686)\end{array}$ \\
\hline Constant & $\mathrm{n} / \mathrm{a}$ & $\begin{array}{r}-0.089 \\
(.812)\end{array}$ & $\begin{array}{r}-1.173 \\
(.458)\end{array}$ & $\begin{array}{r}-0.767 \\
(.097)\end{array}$ & $\begin{array}{r}-0.851 \\
(.655)\end{array}$ \\
\hline \# of observations & & 256 & 256 & 256 & 256 \\
\hline Chi-squared significance & & .972 & .011 & .000 & .000 \\
\hline Cox \& Snell $\mathrm{R}^{2}$ & & .001 & .068 & .232 & .288 \\
\hline Nagelkerke $\mathrm{R}^{2}$ & & .001 & .091 & .309 & .384 \\
\hline
\end{tabular}

(Coefficient results for each independent variable are followed by p-values below.)

\section{Discussion}

We test whether the composition and the compensation of the board of directors of public companies are related to fraudulent corporate behavior. We find that SEC violations are more likely when fewer women sit on the board of directors, when directors have served longer, when there are fewer independent directors, when there are fewer directors with finance/accounting expertise, and when the CEO is also the chair. We also find that common stock and 
stock option compensation, which appear to align directors' incentives with managers, are positively associated with SEC violations. As directors become owners, they have reduced incentive to be active in their oversight role.

The composition and compensation results mentioned above are not only statistically significant; they have clear policy implications that could substantially reduce the likelihood of fraud. Our regression results show that if the chair was also the firm's CEO, the potential conflicts of interest increased the odds ratio by $99.4 \%$. This means that, in our matched sample, the probability of fraud increases from an initial 50\% (half of our sample was fraud firms) to $66.6 \%$ when these two positions are combined.

Each percentage change in the proportion of females on the board reduced the odds ratio by eight percent. With the addition of one female on a typical board with ten directors, the enhanced diverse perspectives and reduced entrenchment translates to reducing the probability of fraud from $50 \%$ to $30.4 \%$. When a dummy variable was used (not reported in our Tables) to compare having at least one female to having none, the probability of fraud decreases from $50 \%$ in the initial sample to $16.4 \%$. Clearly, the presence of a female director can have a significant impact on modifying the board's behavior and improving its oversight function.

Assuming a typical board size of ten members, the addition of one more outside director reduced the odds ratio by $35.6 \%$. This enhanced independence translates to reducing the probability of fraud from $50 \%$ to $39.2 \%$. Similarly, an additional financial/accounting expert reduces the likelihood of fraud from $50 \%$ to $44.3 \%$.

The type of compensation also had significant impact on the likelihood of fraud. As directors' compensation becomes more closely tied to stock prices, incentives are created to manipulate earnings and hide poor performance. A $\$ 10,000$ increase in common stock compensation increased the odds ratio by $16.2 \%$. Compared to our initial matched sample (with $50 \%$ fraud firms), this translates to a predicted increase in the probability of fraud to $53.7 \%$. The impact of using stock options was even stronger, with a $52.2 \%$ increase in the odds ratio for a $\$ 10,000$ increase in stock option compensation. This translates to an increase in the probability of fraud from $50 \%$ in the initial sample to $60.4 \%$. Clearly, the use of options compromises director independence and impairs their ability to provide objective oversight.

This study suggests clear policies to reduce the likelihood of fraud. Since managers who manipulated earnings in our study often appeared to be responding to pressure to meet lofty earnings expectations, careful thought is needed in developing realistic goals and incentive structures. Boards of directors should include more females since women on the board appear to improve board behavior. This improvement may reflect attitudes toward fraud that are unique to women and/or the presence of women on a board serving as a proxy for a less entrenched board. Our proxy statement analysis revealed very little diversity among directors of firms with violations. This suggests that the addition of other diverse directors might have similar impact in reducing fraud. Frequent turnover of board directors should be encouraged. Reducing the length of the elected term is not effective in reducing fraud. Instead, firms should consider term limits to reduce the likelihood of creating an entrenched board. If the oversight function of the board is a priority, the board should include as many independent directors as possible and the chair and CEO positions should be separated.

Finally, incentive-based compensation, such as common stock and especially stock options, should be avoided as part of the compensation to the board and committee members. While stock-based compensation may align otherwise independent directors' incentives with owners and encourage profitability, it also compromises independence and impairs the ability to provide objective oversight. As directors' compensation becomes more closely tied to stock prices, incentives are created to manipulate earnings and hide poor performance. A cash salary appears to be the most effective way to encourage directors to be diligent in constraining practices that compromise financial statement quality or violate securities laws. However, active investors and fund managers may demand performance-based pay, and if this is the case, long-term restricted stock will create fewer conflicts of interest than stock options.

This paper's findings suggest topics for future research. For example, as the number of women on boards of directors increases, it will be easier to disentangle the impact of their presence. At present, when women are sparsely represented, their impact in reducing fraud might proxy for enlightened firms that are more likely to elect women directors and are more concerned with encouraging board turnover. As the presence of women on boards becomes less likely to be a proxy for the above issues, it will be easier to determine if traits unique to women are responsible for reducing fraud. Another potential topic is to examine whether the impact of board composition and compensation on corporate fraud has changed between pre- and post-Sarbanes-Oxley periods.

\section{References}

Abdolmohammadi, M. J., Read, W. J. \& Scarbrough, D. P. (2003). Does Selection-Socialization Help to Explain Accountants' Weak Ethical Reasoning? Journal of Business Ethics, 42(1), 71-81. http://dx.doi.org/10.1023/A:1021691001119 
Adams, R. B. \& Ferreira, D. (2009). Women in the boardroom and their impact on governance and performance. Journal of Financial Economics, 94(2), 291-309. http://dx.doi.org/10.1016/j.jfineco.2008.10.007

Ambrose, M. L. \& Schminke, M. (1999). Sex differences in business ethics: The importance of perceptions. Journal of Managerial Issues, 11 (4), 454-74.

Archambeault, D., DeZoort, F. T., \& Hermanson, D. R. (2008). Audit committee incentive compensation and accounting restatements. Contemporary Accounting Research, 25 (4), 965-992. http://dx.doi.org/10.1506/car.25.4.1

Ballantine, J. (2011). The Impact of Ethical Orientation and Gender on Final Year Undergraduate Auditing Students' Ethical Judgments. Accounting Education, 20(2), 187-201. http://dx.doi.org/10.1080/09639284.2011.557493

Beasley, M. S. (1996). An empirical analysis of the relation between the board of director composition and financial statement fraud. The Accounting Review, 71(4), 443-465.

Beasley, M. S. \& Salterio, S. E. (2001). The relationship between board characteristics and voluntary improvements in audit committee composition and experience. Contemporary Accounting Research, 18(4), 539-570. http://dx.doi.org/10.1506/RM1J-A0YM-3VMV-TAMV

Bebchuk, L. A., Grinstein, Y., \& Peyer, U. (2010). Lucky CEOs and lucky directors. Journal of Finance, 65(6), 2363-2401. http://dx.doi.org/10.1111/j.1540-6261.2010.01618.x

Bierstaker, J. L., Cohen, J. R., DeZoort, F. T., \& Hermanson, D. R. (2012). Audit committee compensation, fairness, and the resolution of accounting disagreements. Auditing, 31(2), 131-150. http://dx.doi.org/10.2308/ajpt-10238

Bilimoria, D. (2000). Building the business case for women corporate directors. In: Burke, R. and Mattis, M. (eds.) Women on Corporate Boards of Directors: International Challenges and Opportunities, 25-40. Kluwer, Dordrecht. http://dx.doi.org/10.1007/978-90-481-3401-4_3

Boumosleh, A. (2009). Director compensation and the reliability of accounting information. The Financial Review, 44, 525-539. http://dx.doi.org/10.1111/j.1540-6288.2009.00228.x

Borkowski, S. C., \& Ugras, Y. J. (1998). Business students and ethics: a meta-analysis. Journal of Business Ethics, 17, 1117-1127. http://dx.doi.org/10.1023/A:1005748725174

Brick, I .E., Palmon, O., \& Wald, J. K. (2006). CEO compensation, director compensation, and firm performance: evidence of cronyism? Journal of Corporate Finance, 12(3), 403-423. http://dx.doi.org/10.1016/j.jcorpfin.2005.08.005

Campbell, K. \& Minguez-Vera, A. (2008). Gender diversity in the boardroom and firm financial performance, Journal of Business Ethics, 83, 435-51. http://dx.doi.org/10.1007/s10551-007-9630-y

Chowdhury, S.D. (2009). Director compensation: the growing popularity of deferred stock units. Ivey Business Journal, 1.

Cox, S. R., Radtke, R. R., (2000). The effects of multiple accountability pressures on tax return preparation decisions. Advances in Taxation, 12, 23-50. http://dx.doi.org/10.1016/S1058-7497(00)12014-9

Cullinan, C.P., Du, H., \& Wright, G.B. (2008). Is there an association between director option compensation and the likelihood of misstatement? Advances in Accounting, 24(1), 16-23. http://dx.doi.org/10.1016/j.adiac.2008.05.003

Crutchley, C. E. \& Minnick, K. (2012). Cash versus incentive compensation: Lawsuits and director pay. Journal of Business Research, 65 (7), 907-913. http://dx.doi.org/10.1016/j.jbusres.2011.05.008

Dechow, P. M., Sloan, R. G., \& Sweeney, A. P. (1996). Causes and consequences of earnings manipulation: an analysis of firms subject to enforcement actions by the sec. Contemporary Accounting Research, 13(1), 1-36. http://dx.doi.org/10.1111/j.1911-3846.1996.tb00489.x

Fondas, N. \& Sassalos, S. (2000). A different voice in the boardroom: How the presence of women directors affects board influence over management. Global Focus, 12, 13-22.

Gavious, I., Segev, E., \& Yosef, R. (2012). Female directors and earnings management in high-technology firms. Pacific Accounting Review, 24(1), 4-32. http://dx.doi.org/10.1108/01140581211221533

Ghosh, A., Marra, A., \& Moon, D. (2010). Corporate boards, audit committees, and earnings management: pre- and post-sox evidence. Journal of Business Finance \& Accounting, 37(9/10), 1145-1176. http://dx.doi.org/10.1111/j.1468-5957.2010.02218.x

Hamdani, A., \& Kraakman, R. (2007). Rewarding outside directors. Michigan Law Review, 105(8), 1677-1711. 
Huse, M. \& Solberg, A. (2006). Gender-related boardroom dynamics: how Scandinavian women make and can make contributions on corporate boards. Women in Management Review, 21, 113-30. http://dx.doi.org/10.1108/09649420610650693

Jensen, M. C. (1993). The modern industrial revolution, exit, and the failure of internal control systems. Journal of Finance, 48(3), 831-880. http://dx.doi.org/10.1111/j.1540-6261.1993.tb04022.x

Kaplan, S.N., \& Reishus, D.(1990). Outside directorships and corporate performance. Journal of Financial Economics, 27(2), 389-410. http://dx.doi.org/10.1016/0304-405X(90)90061-4

Kaplan, S., Pany, K., Samuels, J., \& Zhang, J. (2009). An examination of the association between gender and reporting intentions for fraudulent financial reporting. Journal of Business Ethics, 87, $15-30$. http://dx.doi.org/10.1007/s10551-008-9866-1

Klein, A. (2002). Audit committee, board of director characteristics, and earnings management. Journal of Accounting and Economics, 33(3), 375-400. http://dx.doi.org/10.1016/S0165-4101(02)00059-9

Krause, Ryan A. \& Matthew Semadeni. (2013) Apprentice, departure, and demotion: An examination of the three types of CEO-board chair separation," Forthcoming in the Academy of Management Journal.

Krishnan, G. V. \& Parsons, L. M. (2008). Getting to the bottom line: An exploration of gender and earnings quality. Journal of Business Ethics, 78 (1-2), 65-76. http://dx.doi.org/10.1007/s10551-006-9314-z

Maggina, A. \& Tsaklanganos, A. (2012). Board size: Evidence from Greek public companies. Business Management Dynamics, 1(12), 28-40.

Palmrose, Z.V., Richardson, V.J., \& Scholz, S. (2004). Determinants of market reactions to restatement announcements. Journal of Accounting and Economics, 37(1), 59-89. http://dx.doi.org/10.1016/j.jacceco.2003.06.003

Persons, O. S. (2012). Stock option and cash compensation of independent directors and likelihood of fraudulent financial reporting. Journal of Business \& Economic Studies, 18(1), 54-74.

Peterson, D., Rhoads, A., \& Vaught, B. (2001). Ethical beliefs of business professionals: a study of gender, age and external factors. Journal of Business Ethics, 31, 225-232. http://dx.doi.org/10.1023/A:1010744927551

Razzaque, M. A. \& Hwee, T. P. (2002). Ethics and Purchasing Dilemma: A Singaporean View. Journal of Business Ethics, 35(4), 307-326. http://dx.doi.org/10.1023/A:1013853021571

Rose, C. (2007). Does female board representation influence firm performance? The Danish evidence. Corporate Governance, 15 (2), 404-13. http://dx.doi.org/10.1111/j.1467-8683.2007.00570.x

Sanders, W. G., \& Hambrick, D. C. (2007). Swinging for the fences: The effects of CEO stock options on company risk taking and performance. Academy of Management Journal, 50(5), 1055-1078. http://dx.doi.org/10.5465/AMJ.2007.27156438

Shafer, W. E., Morris, R. E., \& Ketchand, A.A. (2001). Effects of personal values on auditors' ethical decisions. Accounting, Auditing \& Accountability Journal, $254-277$. http://dx.doi.org/10.1108/EUM0000000005517

Srinidhi, B., Gul, F. A., \& Tsui, J. (2011). Female directors and earnings quality. Contemporary Accounting Research, 28(5), 1610-1644. http://dx.doi.org/10.1111/j.1911-3846.2011.01071.x

Sun, J., Liu, G. \& Lan, G. (2011). Does Female Directorship on Independent Audit Committees Constrain Earnings Management? Journal of Business Ethics, 99, 369-382. http://dx.doi.org/10.1007/s10551-010-0657-0

Thorne, L., D. W. Massey, \& Magnan, M. (2003). Institutional context and auditors' moral reasoning: A Canada-U.S. comparison. Journal of Business Ethics, 43 (4), 305-21. http://dx.doi.org/10.1023/A:1023005311277

Vafeas, N. (2003). Length of board tenure and outside director independence. Journal of Business Finance \& Accounting, 30(7/8), 1043-1064. http://dx.doi.org/10.1111/1468-5957.05525

Vafeas, N. (2005). Audit committees, boards, and the quality of reported earnings. Contemporary Accounting Research, 22(4), 1093-1122. http://dx.doi.org/10.1506/1QYN-2RFQ-FKYX-XP84

Vermeir, I. \& Van Kenhove, P. (2007). Gender differences in double standards. Journal of Business Ethics, 81, $281-95$. http://dx.doi.org/10.1007/s10551-007-9494-1

Vnuk, M., Laddin, D., (2010). Director compensation at the 100 largest U.S. public corporations. Compensation Advisory Partners Newsletter, 13, 1-29.

Williamson, O.E., (1984). Corporate governance. The Yale Law Journal, 93, 1197-1230. http://dx.doi.org/10.2307/796256 